Research Article:

\title{
Assessment of Antitumor Activity of Vinca herbacea on Human Ovarian Cancer Cell Line
}

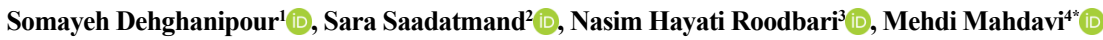 \\ 1. Department of Biology, Science and Research Branch, Islamic Azad University, Tehran, Iran. \\ 2. Recombinant Vaccine Research Center, Tehran University of Medical Sciences, Tehran, Iran. \\ 3. Immunotherapy Group, Institute of Pharmaceutical Sciences, Tehran University of Medical Sciences, Tehran, Iran \\ 4. Department of Immunology, Pasteur Institute of Iran, Tehran, Iran.
}

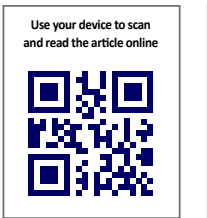

Citation Dehghanipour S, Saadatmand S, Hayati Roodbari N, Mahdavi M. Assessment of Antitumor Activity of Vinca herbacea on Human Ovarian Cancer Cell Line. Immunoregulation. 2020; 3(2):115-126. http://dx.doi.org/10.32598/Immunoregulation.3.2.6

doi) http://dx.doi.org/10.32598/Immunoregulation.3.2.6

\section{Article info:}

Received: 29 Mar 2020

Accepted: 02 June 2020

Available Online: 01 Jan 2021

Keywords:

Vinca herbacea extract, Ovarian cancer,

Angiogenesis, Apoptosis, Antitumor

\begin{abstract}
A B S T RA C T
Background: It seems that Vinca. herbacea has an anti-tumor effect. Here, the immunotherapeutic effect of this compound is assessed against human ovarian cancer (SKOV3) cells because of the high incidence of this tumor in women.

Materials and Methods: The cytotoxic activity of V. herbacea extract against human ovarian cancer (SKOV3) cells was determined by MTT assay. The apoptosis-inducing potential of V. herbacea extract was investigated using the FITC-V Annexin kit. The Matrigel invasion assay was used to investigate the ability of V. herbacea extract in reducing ovarian cancer cells invasion. Real-time PCR using specific primers was performed to investigate the expression of angiogenesis (VEGFR1, VEGFR2, and $V E G F-A)$, apoptosis ( $B c l-2$ and $B a x$ ), and metastasis (MMP2 and $M M P 9$ ) genes.

Results: V. herbacea caused a significant cytotoxic effect against human ovarian cancer cells in a dose-dependent manner. V. herbacea induced apoptosis in SKOV3 cells through caspase-3 activation and an increase in the expression ratio of $\mathrm{Bax} / \mathrm{Bcl}-2$. V. herbacea inhibited cancer cells' angiogenesis, which was evident by the significant reduction in the expression of angiogenesis-related genes, including VEGF, VEGFR-1, and VEGFR-2. Besides, V. herbacea inhibited cancer cell adhesion and invasion.

Conclusion: V. herbacea extract elicits a robust cytostatic effect in SKOV3 cells by modulating the activity and or the expression of proteins regulating the process of cellular apoptosis, adhesion invasion, and angiogenesis.
\end{abstract}

\footnotetext{
* Corresponding Author:

Mehdi Mahdavi, PhD.

Address: Department of Immunology, Pasteur Institute of Iran, Tehran, Iran.

Phone: +98 (21) 44865323

E-mail:mahdavivac@gmail.com
} 


\section{Introduction}

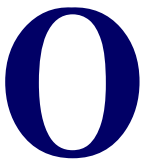

varian cancer is the third most common and highly lethal gynecological malignant tumor in the female reproductive system. It presents a major challenge to healthcare systems throughout the world, due to its aggressive growth, rapid metastasis, strong invasion, and poor prognosis $[1,2]$.

The incidence of ovarian cancer is considerable worldwide and mainly diagnosed at an advanced stage. The prognosis of this cancer is poor, which makes this the most lethal gynecological malignancy. In the recent 10 years, an increase in this cancer incidence was mainly observed in Central and South America, Asia, as well as Central and Eastern Europe [3]. However, after 2011 in some countries such as the Netherlands, the incidence declined [4].

At present, chemotherapy is a major therapeutic option for ovarian cancer. Patients are frequently attenuated by developing resistance to a wide spectrum of the classic anticancer agents and considerable adverse side effects such as systemic toxicity. Although primary treatment has enhanced the 5-year survival rate, it has not improved the overall rate of cure, because the percentage of relapsed ovarian cancer patients who developed resistance to taxane- or platinum-based treatment has increased to more than $70 \%$ [5-7]. It was reported that $28 \%$ of ovarian cancer patients entering their last stage of life, develop malignant ascites resistant to conventional chemotherapy [8]. The high incidence and mortality of ovarian cancer, combined with the paucity of effective anticancer agents $[2,9]$, highlights designing effective therapeutic approaches, as well as aiding the treatment and control of ovarian cancer patients worldwide. The examination and identification of medicinal plants as major sources of effective anti-cancer agents have been growing to develop new therapeutic agents for metastatic ovarian cancer $[10,11]$.

Vinca herbacea Waldst. et Kit. belongs to the Apocynaceae family, which is an herbaceous perennial plant growing as a trailing vine and distributed in various geographical areas, especially in the Alborz mountains in northern Iran [12-14]. Total alkaloids in various parts of $V$. herbacea is associated with different pharmacological activities, including long-time reduction effects on blood pressure, inhibitory effect on neuromuscular synapses, bacteriostatic effect, and cardio-stimulating activity [15-17]. Oxindole alkaloids establish the main anti-cancer compounds of V. herbacea, including vinblastine, vincristine, vindesine, and vinorelbine are widely used antineoplastic drugs. The mechanism of action of these cell cycle-dependent agents is the inhibi- tion of tubulin polymerization into microtubules [18]. Besides, the study of leukopenia-induced mice showed that treatment with $V$. herbacea could restitute WBCs count of immunocompetent mice and thereby potentiating the immune response [19].

However, the exact mechanism of antitumor activities of $V$. herbacea leaf extract is unknown, and especially, studies regarding its effects on adhesion, invasion, and apoptosis pathway of ovarian cancer are unavailable. In this study, in vitro antitumor activity of $V$. herbacea leaf extract was examined by assessing cell viability, adhesion/invasion, and apoptosis pathway in human ovarian cancer cells.

\section{Materials and Methods}

\section{Plant material and extract preparation}

The leaves of $V$. herbacea were collected in the flowering phase (May 2017) from Alborz mountain in Alborz Province, Iran. The plant was identified in the Department of Pharmacology at Tehran University of Medical Sciences [Herbarium \#6601]. The plant leaves were cleaned, weighed, dried, pulverized, and macerated in ethanol $(70 \%)$ at room temperature for 3 days with shaking. The extract was passed through a filter paper and liquid sample concentrated in a rotary evaporator (LABORATA 4000 efficient Heidolph, Germany) and finally lyophilized in a freeze dryer (LTE Scientific $\mathrm{Ltd}, \mathrm{UK})$. The obtained powder was stored at $-20^{\circ} \mathrm{C}$ until further use. The working solutions were prepared by dissolving the extract in dimethyl sulfoxide $0.5 \% \mathrm{v} / \mathrm{v}$ (DMSO, Sigma-Aldrich, USA) for experiments.

\section{Cell culture}

SKOV3 (Human ovarian cancer) and HEK 293 (Human embryonic kidney cells 293) cell lines were purchased from Pasteur Institute (Tehran, Iran) and cultured in tissue culture flask with high glucose Dulbecco's modified eagle medium (DMEM; Gibco, USA) supplemented with $10 \%$ fetal bovine serum (FBS, Gibco) and $100 \mathrm{U} / \mathrm{mL}$ penicillin-streptomycin and kept at $37^{\circ} \mathrm{C}$ in a humidified $5 \% \mathrm{CO} 2$ incubator for $72 \mathrm{~h}$

\section{Cytotoxicity assay}

Cytotoxicity assay was evaluated with 3-(4,5-dimethylthiazol-2-yl)-2,5-diphenyltetrazolium bromide (MTT) as described previously [20, 21]. Briefly,

$1 \times 10^{5}$ cells $/ \mathrm{mL}$ was treated with various doses (10 to $1000 \mu \mathrm{g} / \mathrm{mL}$ ) of $V$. herbacea extract for 24 and 48 hours 
Subsequently, the cells were treated with MTT solution (Sigma-Aldrich) and then the culture medium was replaced with DMSO and the Absorbance (Ab) was measured at 570 $\mathrm{nm}$ using an ELISA microplate reader. The percentage of cytotoxicity activity was calculated as follows: cytotoxicity activity $(\%)=[1-(\mathrm{Ab}$ of experimental well/Ab of negative control well) $] \times 100$. The $\mathrm{IC}_{50}$ (concentration that inhibits cell growth by $50 \%$ ) value of $V$. herbacea extract was calculated via nonlinear regression of concentration-response curves.

\section{Cell apoptosis assay}

Annexin V-FITC/PI staining assay was performed to identify apoptotic cells as previously described [22]. Briefly, the cells $\left(2 \times 10_{5}\right.$ cells/well $)$ were treated with an $\mathrm{IC}_{50}$ dose of $V$. herbacea extract. Subsequently, the cells were centrifuged and stained with Annexin V-FITC solution (BD, USA) and PI (Sigma). The cells were analyzed using a FACScan flow cytometer (BD) and FlowJo software version 9.0 (Tree Star, USA).

\section{Caspase- 3 and caspase-9 activation assay}

Caspase- 3 and caspase- 9 activities were measured by using a caspase- 3 or caspase- 9 colorimetric assay kit (Abcam, Cambridge, MA, USA) according to the manufacturer's instruction. Briefly, cell suspensions $\left(2 \times 10^{6}\right.$ cells/well $)$ were treated for $24 \mathrm{~h}$ with an $\mathrm{IC}_{50}$ dose of $V$. herbacea extract. The cells were harvested and washed three times with PBS and lyzed using $50 \mu \mathrm{L}$ of lysis buffer for $10 \mathrm{~min}$ on ice. The lyzed samples were centrifuged at $15000 \mathrm{rpm}$ at $4^{\circ} \mathrm{C}$ for $1 \mathrm{~min}$ and the supernatant was collected and total protein concentration was assessed using Bradford reagent. The samples adjusted to the concentration of $200 \mu \mathrm{g}$ per $50 \mu \mathrm{L}$ of lysis buffer and $50 \mu \mathrm{L}$ of this sample were added to the 96-well plate (Greiner, Germany) as a test and for background well, the lysis buffer was added. Afterward, $50 \mu \mathrm{L}$ of $2 \mathrm{x}$ reaction buffer $(10 \mathrm{mM}$ DTT) was added to each well and then $5 \mu \mathrm{L}$ of the $4 \mathrm{mM}$ DEVD-p-NA substrate (200 $\mu \mathrm{M})$ was added to the wells and incubated for $2 \mathrm{~h}$ at $37^{\circ} \mathrm{C}$. The optical density of the reaction was measured at $405 \mathrm{~nm}$ on a microplate reader. Fold-increase of caspase- 3 and -9 activity was determined by comparing sample (treated) results with untreated wells.

\section{Adhesion assay}

Adhesion assay was performed as previously described [23]. Briefly, V. herbacea extract-treated and extract-untreated cells were fixed with methanol and subsequently stained with $1 \%$ toluidine blue and solubilized in $1 \%$ SDS. After color development, absorbance at $540 \mathrm{~nm}$ was measured.

\section{Matrigel invasion assay}

Matrigel invasion assay was performed as previously described [23]. Briefly, the upper and lower transwell chambers (Corning, USA) were filled with RPMI-1640 diluted Matrigel (Corning) and RPMI-1640 containing $10 \% \mathrm{FBS}$, respectively, and incubated for $30 \mathrm{~min}$ at $37^{\circ} \mathrm{C}$. The cells were treated with $V$. herbacea extract for $24 \mathrm{~h}$, then they were incubated at upper chambers for $5 \mathrm{~h}$ at $37^{\circ} \mathrm{C}$ with $5 \% \mathrm{CO} 2$. After the removal of non-invading cells with a cotton swab from the top of the membrane, cells underneath the membrane filter were fixed in paraformaldehyde $(3.7 \%)$ for $15 \mathrm{~min}$, stained with $0.1 \%$ toluidine blue solution for $2 \mathrm{~min}$ at $37^{\circ} \mathrm{C}$. Then the invaded cells underneath the membrane were stained with toluidine blue solution. The suspension was solubilized in $1 \% \mathrm{SDS}$ and absorbance was measured at $600 \mathrm{~nm}$.

\section{Reverse transcriptase-polymerase chain reaction}

The mRNA expression of apoptosis regulatory genes (Bax and Bcl-2), angiogenesis genes (VEGF-A, VEG$F R-1$, and VEGFR-2), and metastasis genes (MMP-2 and $M M P 9$ ) was evaluated by SYBR Green real-time PCR analysis using specific oligonucleotide primers as previously described [24, 25]. GAPDH was used as internal control (Appendix 1).

\section{Statistical analysis}

GraphPad Prism 6 (GraphPad Prism version 6.01 Software, Inc., USA) was used to perform statistical analyses. The results were analyzed with a One-way analysis of variance and Dunnett's post hoc test. All values were presented as the Mean \pm SEM, and a P value of less than 0.05 was considered statistically significant.

\section{Results}

\section{V. herbacea extract has high cytotoxic activity against SKOV3}

The cytotoxic activity of $V$. herbacea extract against SKOV3 cells (Figure 1A) was determined by the MTT assay. Here, HEK 293 cells (Figure 1B) were used as the control. Results show that treatment with $V$. herbacea extract significantly decreased SKOV3 cell viability. $V$. herbacea extract at a concentration of $800 \mu \mathrm{g} / \mathrm{mL}$ showed the highest cytotoxicity activity against SKOV3 cells, with cell viability of $19 \%(\mathrm{P}<0.05)$. The cytotoxicity activity of $V$. herbacea extract against SKOV3 cells at all concentrations was significantly higher than untreated-cells $(\mathrm{P}<0.01)$ and the $\mathrm{IC}_{50}$ value of $V$. herba- 
cea extract was $10.64 \mu \mathrm{g} / \mathrm{mL}$. As shown in Figure 1B, $V$. herbacea extract at concentrations of 10 to $150 \mu \mathrm{g} / \mathrm{mL}$ has no significant cytotoxic activity on HEK 293 cells compared to untreated-cells $(\mathrm{P}>0.05)$. It is worth mentioning that the $\mathrm{IC}_{50}$ value of $V$. herbacea extract against HEK 293 cells was $251.2 \mu \mathrm{g} / \mathrm{mL}$, which was significantly higher than the $\mathrm{IC}_{50}$ value of $V$. herbacea extract against SKOV3 cells. Also, there was no significant difference regarding the cytotoxic activity of $V$. herbacea extract between 24 and $48 \mathrm{~h}$ treatments (data not shown).

\section{V. herbacea extract induces apoptosis of SKOV3}

To test whether the cytotoxic effect of $V$. herbacea extract on SKOV3 cells was due to apoptosis, Annexin V/ PI staining was carried out. Treatment of SKOV3 cells with $V$. herbacea extract at a concentration of $10.64 \mu \mathrm{g} /$ $\mathrm{mL}$ significantly increased the percentage of early apoptotic cells from $3.1 \%$ in the control cells to $27.1 \%$ in the treated cells $(\mathrm{P}<0.05)$. The population of late-stage apoptotic cells after treatment with $V$. herbacea extract significantly increased to $12.5 \%$, compared to that in the control cells $(2 \%)(\mathrm{P}<0.05)$. In the presence of $V$. herbacea extract, the number of early cells significantly increased $(\mathrm{P}<0.05)$ compared to that in the late apoptotic cells $(\mathrm{P}<0.01$; Figure $2, \mathrm{~A}$ and $\mathrm{B})$.

Moreover, to evaluate the cell apoptosis pathway induced by $V$. herbacea extract, we measured the caspase- 3 and caspase- 9 activities in the experimental cell lines. Results show that treatment with $V$. herbacea extract at a concentration of $10.64 \mu \mathrm{g} / \mathrm{mL}$ significantly increased the caspase- 3 activity by 1.8 fold, compared to the control cells ( $\mathrm{P}<0.05$; Figure. $3 \mathrm{~A})$. Also, caspase- 9 activity after treatment with $10.64 \mu \mathrm{g} / \mathrm{mL}$ of $V$. herbacea extract significantly increased by 1.5 folds compared to the control cells $(\mathrm{P}<0.05$; Figure $3 \mathrm{~B})$.

Next, we assessed the expression level of apoptosisrelated genes, Bax (Figure 3C) and Bcl-2 (Figure 3D) in $V$. herbacea extract-treated SKOV3 cells by RT-PCR. The relative expression of the genes was determined by dividing its expression amount by that of the GAPDH gene. Results show that incubation of cells with $V$. herbacea extract resulted in a significant decrease of antiapoptotic $B c l-2$ mRNA expression and also associated with a marked increase in the expression of pro-apoptotic Bax mRNA $(\mathrm{P}<0.05)$. The expression level of Bax mRNA was 1.7 folds after the treatment. Moreover, the expression level of $B c l-2$ gene was decreased by 0.3 fold when the SKOV3 cells were treated with $V$. herbacea extract $(\mathrm{P}>0.05)$.

$V$. herbacea extract decreases tumor cell adhesion, invasion, and metastasis

To assess the anti-adhesive effects of $V$. herbacea extract, SKOV3 cells were incubated with $\mathrm{IC}_{50}$ concentration of $V$. herbacea extract, and attached cells were quantitated colorimetrically using an ELISA plate reader. As shown in Figure 4, the treatment of tumor cells with

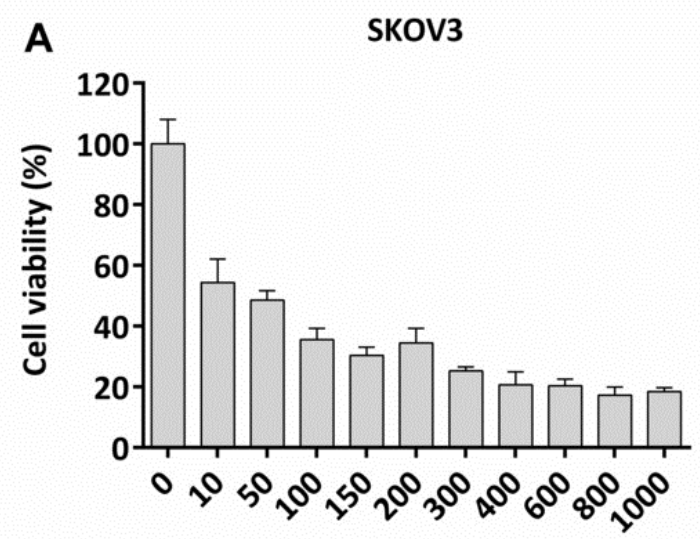

Concentration $\mu \mathrm{g} / \mathrm{ml}$
B HEK 293

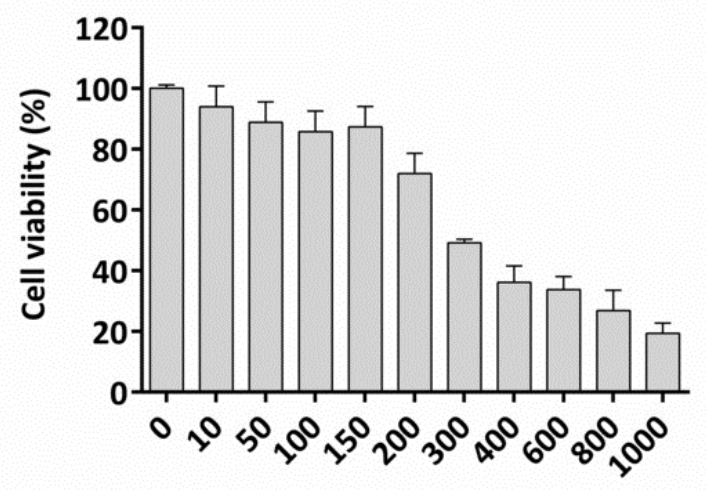

Concentration $\mu \mathrm{g} / \mathrm{ml}$

Figure 1. Comparative analysis of cytotoxic effects of $V$. herbacea extract on SKOV3 and HEK 293 cell lines IMMUNoReGULATION A: SKOV3; and B: HEK 293 cell lines were incubated with different concentrations of $V$. herbacea extract (10-1000 $\mu \mathrm{g} / \mathrm{mL})$. HEK 293 cell line was used as a control. The compound suppressed cell viability on the SKOV3 cell line at all concentrations but does not show a dramatic toxicity effect on the HEK293 cell line at concentrations below $150 \mu \mathrm{g} / \mathrm{mL}$. 


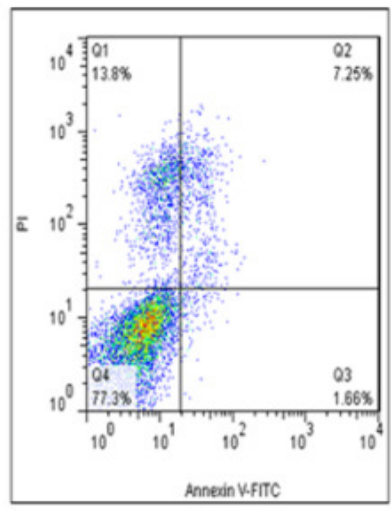

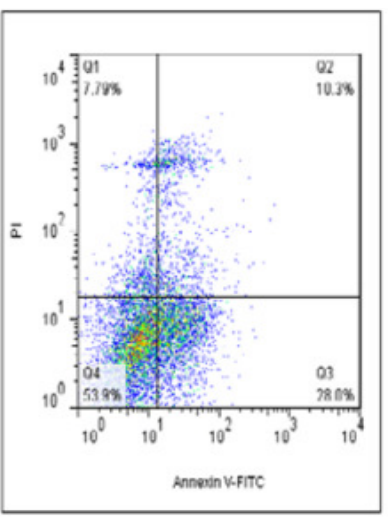

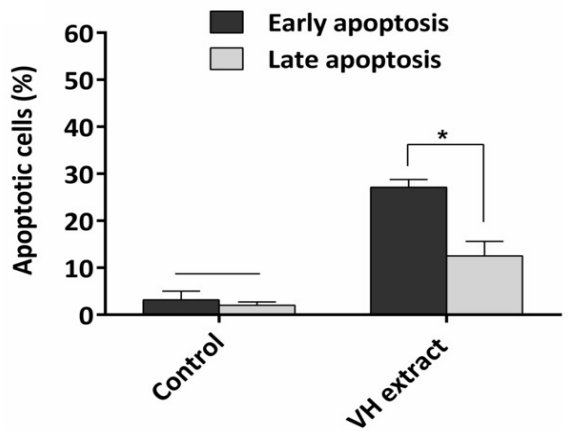

IMnUNoReguLATION

Figure 2. Effect of $V$. herbacea extract on SKOV3 cell apoptosis

Flow cytometry analysis of SKOV3 treated with $10.64 \mu \mathrm{g} / \mathrm{mL}$. herbacea extract for $24 \mathrm{~h}$. (A) Representative scatter plots of PI (y-axis) vs. Annexin V (x-axis). Representative figures showing the population of viable (Annexin V-PI-), early apoptotic (Annexin V+ PI-), late apoptotic (Annexin $\mathrm{V}+\mathrm{PI}^{+}$), and necrotic (Annexin $\mathrm{V}-\mathrm{PI}^{+}$) cells. (B) $V$. herbacea extract at a concentration of $10.64 \mu \mathrm{g} / \mathrm{mL}$ significantly increased the percentage of early apoptotic cells from $3.1 \%$ in untreated cells to $27.1 \%(\mathrm{P}<0.05)$. The population of late-stage apoptotic cells after treatment with $V$. herbacea extract significantly increased to 12.5 , compared to that in the untreated-cells $(2 \%)(\mathrm{P}<0.05)$. Data are presented as Mean \pm SEM of three independent experiments. ${ }^{*}<0.05$ indicates the groups, which were significantly different.

$10.64 \mu \mathrm{g} / \mathrm{mL}$ of $V$. herbacea extract significantly reduced cell adhesion compared to the control cells $(\mathrm{P}<0.05)$.

To determine the inhibitory effects of $V$. herbacea extract on SKOV3 cells invasion, we performed a Matrigel invasion assay. As shown in Figure 5A. V. herbacea extract decreased the SKOV3 cell invasion to the Matrigel-coated substrate. Treatment of SKOV3 cells with $10.64 \mu \mathrm{g} / \mathrm{mL}$ of $V$. herbacea extract significantly decreased tumor cell invasion by $30 \%$ compared to that in the untreated-cells $(\mathrm{P}<0.05)$. Moreover, we assessed the expression level of metastasis-related genes, MMP2 and MMP9, in $V$. herbacea extract-treated SKOV3 cells by RT-PCR. The expressions of MMP2 and MMP9 were both decreased by $V$. herbacea extract treatment versus the control sample. As shown in Figure 5B, the treatment of SKOV3 cells with $10.64 \mu \mathrm{g} / \mathrm{mL}$ of $V$. herbacea extract significantly reduced transcription of MMP2 by 0.7 fold compared with the control cells $(\mathrm{P}<0.05)$. Moreover, the expression level of the MMP9 gene decreased by 0.7 fold when the SKOV3 cells were treated with $10.64 \mu \mathrm{g} / \mathrm{mL}$ of $V$. herbacea extract in comparison to the control cells.

\section{$V$. herbacea extract inhibits angiogenesis of tu-} mor cells

To evaluate the possible anti-angiogenic effect of $V$. herbacea extract, we evaluated VEGF-A, VEGFR-1, and VEGFR-2 mRNA expression. The relative expression of the genes was determined by dividing its expression amount by that of the GAPDH gene. Results demonstrate the expression level of VEGF-A, VEGFR-1, and VEGFR-2 mRNA in $V$. herbacea extract-treated cells decreased in comparison to the control cells. As shown in Figure 6A, the treatment of SKOV3 cells with $10.64 \mu \mathrm{g} / \mathrm{mL}$ of $V$. herbacea extract significantly reduced transcription of VEGFR-1 by 0.8 fold compared with the control cells $(\mathrm{P}<0.05)$. Moreover, Figure $6 \mathrm{~B}$ indicates that the expression level of the VEGFR-2 gene decreased by 0.7 fold when the SKOV3 cells were treated as well. Also, the treatment of SKOV3 cells with 10.64 $\mu \mathrm{g} / \mathrm{mL}$ of $V$. herbacea extract decreased the mRNA levels of VEGF-A by 0.7 fold as compared with the control cells $(\mathrm{P}<0.05$; Figure $6 \mathrm{C})$.

\section{Discussion}

Ovarian cancer is currently the most common cause of death among other gynecologic cancers in women worldwide [26, 27].

The survival rate of ovarian cancer patients is not only associated with the disease stages but also the ovarian cell types. High-grade serous adenocarcinoma is the most common histologic subtype with the worst prognosis $[19,28,29]$. In the present study, SKOV3 was used for assessing the anti-proliferative and apoptosispromoting effects of $V$. herbacea in vitro.

When assessing the in vitro cytotoxic activity of $V$. herbacea extract-induced cell death against SKOV3 cells, we found that $V$. herbacea extract has anti-proliferative activity in a dose-dependent manner, as reflected by the low cytotoxic effects on HEK 293 cells. 
A

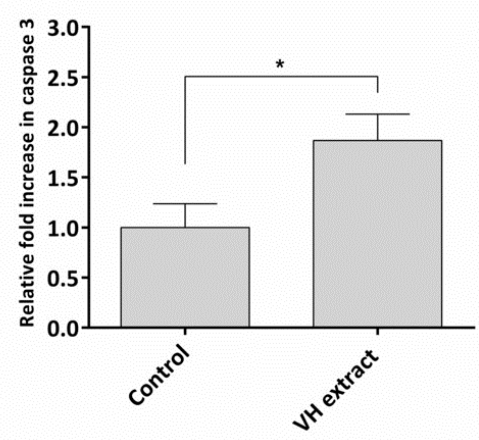

C

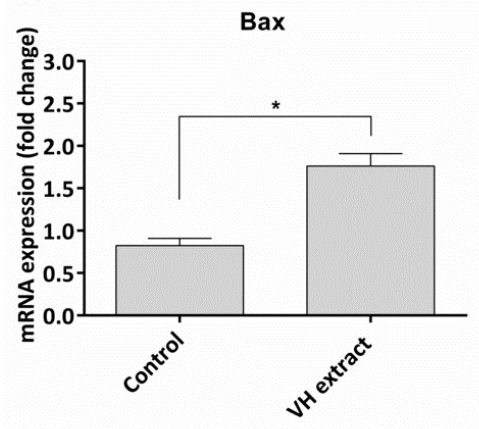

B

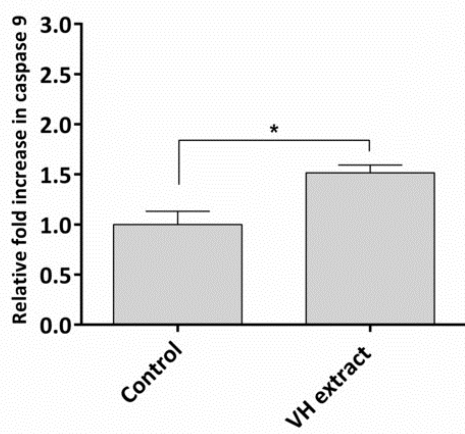

D

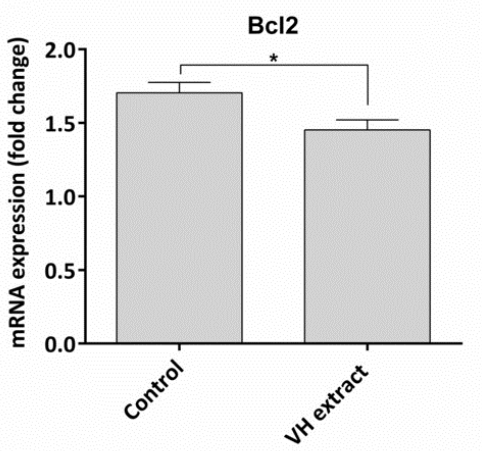

IMMUNoRegulation

Figure 3. The caspase-3 and caspase- 9 activities in the experimental cell lines

A: Caspase-3 and B: Caspase-9 activities in SKOV3 cells after treatment with $\mathrm{IC}_{50}$ concentration of $V$. herbacea extract

Treatment with $V$. herbacea extract increased caspase- 3 activity by 1.8 fold and caspase- 9 activity by 1.5 fold compared to the control cells $(\mathrm{P}<0.05)$.

C: Besides, relative mRNA levels of $B a x$ and D: Bcl-2 (in treated SKOV3 cells versus untreated cells. Incubation of the cells with $V$. herbacea extract at $\mathrm{IC}_{50}$ concentration resulted in a significant decrease in the $B c l-2 \mathrm{mRNA}$ expression while associated with a marked increase in the expression of Bax mRNA $(\mathrm{P}<0.05)$. Data are presented as the Mean \pm SEM of three independent experiments. ${ }^{*} \mathrm{P}<0.05$ indicates the groups, which were significantly different.

In the MTT assay, the number of metabolically active viable cells is associated with the reduction of MTT by mitochondrial dehydrogenase enzyme [30]. The results of the MTT assay indicated that $V$. herbacea extract has a great potential to inhibit cell proliferation and induce death in human ovarian cancer cells. The study also demonstrates that the $V$. herbacea extract has poor effects on the growth and metabolism of normal cells, which are the most suitable attributes of a chemotherapeutic drug; therefore, this potential should be considered during further drug development.

We further used Annexin/PI flow cytometric assays to assess the pathways of cell death induced by $V$. herbacea extract. Analysis of flow cytometric results demonstrated that $V$. herbacea extract treatment resulted in an increased number of cells undergoing early and late apoptosis. The results suggested that $V$. herbacea extract induces translo- cation of phosphatidylserine from inner to the outer surface of the cell membrane, which is generally accepted as one of the biomarkers of apoptosis [31]. Unlike necrosis, apoptosis preserves tissue homeostasis by removing dead cells by immune cells such as macrophages and does not induce inflammatory responses, which destroys normal cells and tissue damage [32]. To maintain their uncontrolled proliferation, cancer cells acquire and show different resistance mechanisms to apoptosis; therefore, because of its apoptosis-inducing potential, $V$. herbacea extract can be considered a probable chemotherapeutic agent against cancer in future studies [33].

Apoptosis or programmed cell death is a highly complex process and classified into caspase-dependent or caspase-independent mechanisms [34]. The caspasedependent pathway is further divided into the extrinsic (death receptor) and the intrinsic (mitochondrial) cas- 


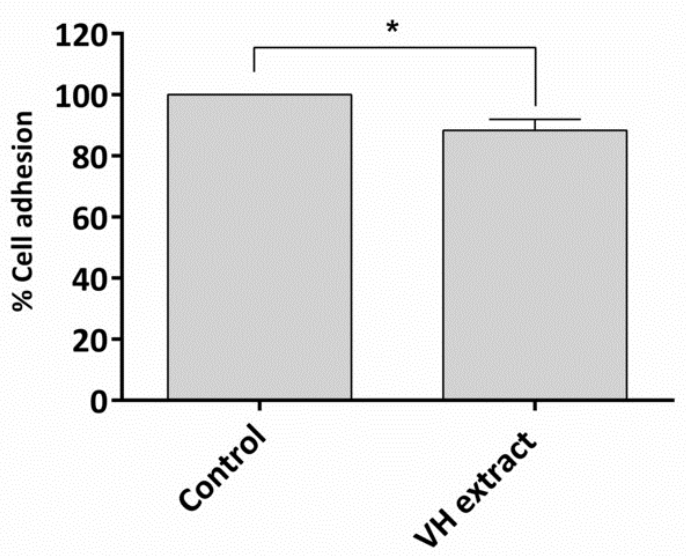

Figure 4. Effect of $V$. herbacea extract on SKOV3 cell adhesion

IMMUNoRegLLATION Data are presented as the Mean \pm SEM of three independent experiments. ${ }^{*}<<0.05$ indicates the groups, which were significantly different.

cades, as determined by the involvement of caspase- 8 or caspase-9, respectively [34]. Both pathways activate caspase- 3 that is involved in the final execution of dying cells, while caspase- 9 is an initiator caspase that is involved in the intrinsic pathway [34]. A study reported the anticancer effects of $V$. herbacea extract but the mechanisms of cancer cell apoptosis have not been elucidated [35]. In assessing the molecular mechanism underlying the apoptosis process, we found that $V$. herbacea extract induced an increase in caspase- 9 and caspase- 3 activities, which confirms the contribution of intrinsic caspase pathways in the $V$. herbacea extract- induced cell death. Moreover, the apoptotic effects of $V$. herbacea extract in SKOV3 cells were confirmed by the up-regulation of Bax and down-regulation of Bcl-2, which are the key genes in the intrinsic pathway of apoptosis [36].

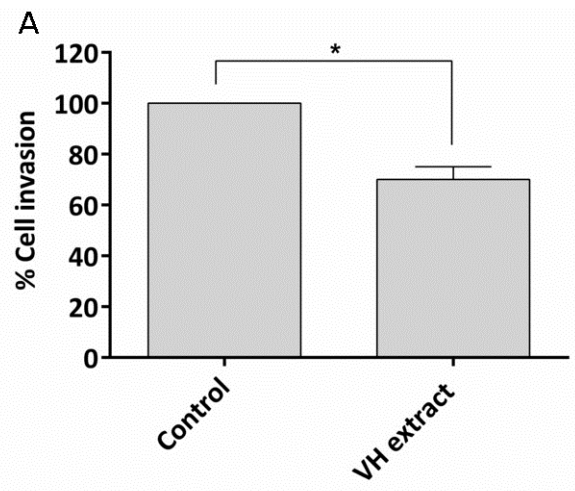

Figure 5. Effect of $V$. herbacea extract

A: SKOV3 cell invasion; and B: Metastasis

${ }^{*} \mathrm{P}<0.05$ indicates the groups, which were significantly different.
The in vitro, antitumor proliferation and activity of many drug components are accomplished through the Bax/Bcl-2 pathways [37-39]. However, the in vivo association between clinical prognostic factors and $\mathrm{Bcl}-2$ and Bax mRNA expression is variable [40, 41]. These findings support the notion that $V$. herbacea extract reduced the survival and inhibited the growth of ovarian cancer cell via both intrinsic and extrinsic apoptosis pathways, which may have therapeutic potential in the management of ovarian cancer.

It is well known that the development of tumor cell invasion and metastasis is a dynamic multi-step process, including cell adhesion, proteolytic degradation, migration, and angiogenesis [42]. Targeted anti-cancer drugs block cell cycle progression by interfering with specific 

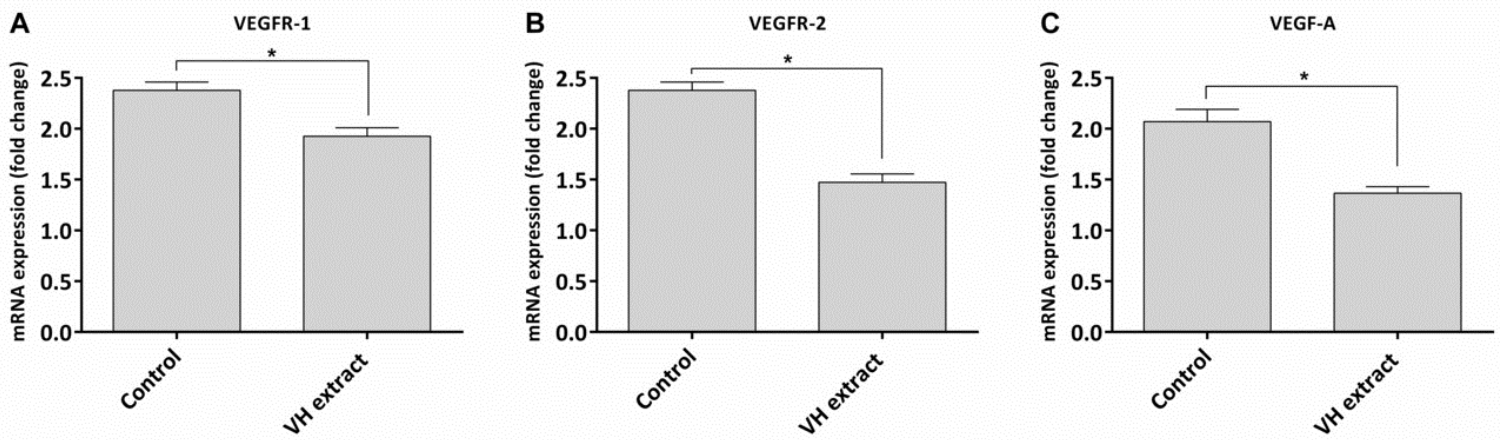

IMMUNoREGULATION

Figure 6. Quantitative PCR analysis of angiogenesis-associated genes in $V$. herbacea extract-treated SKOV3 cells

A: Relative mRNA levels for VEGF-1; B: VEGFR-2; and C: VEGFR-A in treated SKOV3 cells versus untreated cells are expressed as the Mean $\pm S D$ of three independent experiments. ${ }^{*}<0.05$ indicates the groups which were significantly different.

molecules, which have critical roles in tumor cell growth, survival, migration, and invasive spread of cancer [43, 44]. Currently, there is increasing attention toward the combination of multiple anticancer agents, which target and interfere with several pathways [45]. Data from the potency assessment of $V$. herbacea extract showed that the effective inhibition of adhesion and invasion of the treated-SKOV3 cell, which is evident by the significant reduction of the invaded cell to the Matrigel-coated substrate, may be due to the death of the $V$. herbacea-treated cells.

In assessing the mechanism by which $V$. herbacea extract inhibits tumor growth and invasion, we found that $V$. herbacea extract efficiently inhibited ovarian cancer cells' angiogenesis, which was evident by the significant reduction in the expression of angiogenesis-related genes, including VEGF and its tyrosine kinase receptors, VEGFR-1 and VEGFR-2. Since the exceeding concentrations of angiogenesis inhibitors against those of stimulators could potentially inhibit the tumor growth and dissemination to other organs, inhibition of angiogenesis is a critical step for cancer prevention and treatment [46]. VEGF, VEGFR-1, and VEGFR-2 are identified as common anti-angiogenic target molecules because they are key mediators of angiogenesis [47]. It is worth noting that RT-PCR analysis revealed that $V$. herbacea extract decreases the expression of the VEGF-A, VEGFR-1, and VEGFR-2 genes, which can contribute to its anti-tumor activities through inhibition of tumor angiogenesis. Considering the potential of $V$. herbacea extract to inhibit tumor invasion and metastasis, we found that $V$. herbacea extract markedly reduced the expression level of MMP-2 and MMP-9 in SKOV3 cells. It is well known that the inhibition of MMPs prevents tumor invasion and metastasis $[29,48,49]$. Also, SKOV3 cells, which are identified as high-grade serous adenocarcinoma, have a high metastatic rate $[9,28,29]$. It has been documented that in advanced ovarian serous cancers the elevated MMP level, particularly MMP-2 and MMP-9, associates with tumor progression and metastasis [50-53]. Together, the results of the current study indicate that $V$. herbacea extract can have an inhibitory effect on the invasion and metastasis of SKOV3.

We report that the $V$. herbacea extract may be useful as a therapeutic option against ovarian cancer because it elicits a robust cytostatic effect in SKOV3 cells by affecting the activity and or the expression of genes regulating the process of cellular apoptosis, adhesion, invasion, and angiogenesis. In light of these findings, a thorough assessment of $V$. herbacea extract under controlled clinical settings against different tumor cells seems warranted. Our results reinforce the promise that, perhaps soon, clinical applications of the therapeutic potential of $V$. herbacea extract can provide patients with an extended range of protection, and help reduce the high morbidity and mortality associated with cancer around the world.

\section{Ethical Considerations}

\section{Compliance with ethical guidelines}

This is a in vitro study. All experiments have performed according to the Helsinki principals.

Funding

This project was supported partially by the Science and Research Branch, Islamic Azad University, Tehran, and Pasteur Institute of Iran.

Authors' contributions 
All authors equally contributed in preparing this article.

\section{Conflicts of interest}

The authors declare no conflict of interest.

\section{References}

[1] Siegel RL, Miller KD, Jemal A. Cancer statistics, 2016. CA: A Cancer Journal for Clinicians. 2016; 66(1):7-30. [DOI:10.3322/ caac.21387] [PMID]

[2] Torre LA, Trabert B, DeSantis CE, Miller KD, Samimi G, Runowicz CD, et al. Ovarian cancer statistics, 2018. CA: A Cancer Journal for Clinicians. 2018; 68(4):284-96. [DOI:10.10.3322/ caac.21456]

[3] Zhang Y, Luo G, Li M, Guo P, Xiao Y, Ji H, et al. Global patterns and trends in ovarian cancer incidence: Age, period and birth cohort analysis. BMC Cancer. 2019; 19(1):984. [DOI:10.1186/ s12885-019-6139-6] [PMID] [PMCID]

[4] Schuurman MS, Timmermans M, van Gorp T, de Vijver KKV, Kruitwagen $R$, Lemmens $V$, et al. Trends in incidence, treatment and survival of borderline ovarian tumors in the Netherlands: A nationwide analysis. Acta Oncologica (Stockholm, Sweden). 2019; 58(7):983-9. [DOI:10.1080/0284186X.2019.1619935] [PMID]

[5] Beller U, Quinn MA, Benedet JL, Creasman WT, Ngan HY, Maisonneuve $\mathrm{P}$, et al. Carcinoma of the vulva. FIGO $26^{\text {th }}$ annual report on the results of treatment in gynecological cancer. International Journal of Gynecology \& Obstetrics. 2006; 95(Suppl 1):S7-27. [DOI:10.1016/S0020-7292(06)60028-3]

[6] Chen H, Hardy TM, Tollefsbol TO. Epigenomics of ovarian cancer and its chemoprevention. Frontiers in Genetics. 2011; 2:67. [DOI:10.3389/fgene.2011.00067] [PMID] [PMCID]

[7] Monk BJ, Coleman RL. Changing the paradigm in the treatment of platinum-sensitive recurrent ovarian cancer: From platinum doublets to nonplatinum doublets and adding antiangiogenesis compounds. International Journal of Gynecological Cancer. 2009; 19 Suppl 2:S63-7. [DOI:10.1111/IGC.0b013e3181c104fa] [PMID]

[8] Bellati F, Napoletano C, Ruscito I, Pastore M, Pernice M, Antonilli $\mathrm{M}$, et al. Complete remission of ovarian cancer induced intractable malignant ascites with intraperitoneal bevacizumab. Immunological observations and a literature review. Investigational New Drugs. 2010; 28(6):887-94. [DOI:10.1007/s10637-0099351-4] [PMID]

[9] Reid BM, Permuth JB, Sellers TA. Epidemiology of ovarian cancer: A review. Cancer Biology \& Medicine. 2017; 14(1):9-32. [DOI:10.20892/j.issn.2095-3941.2016.0084] [PMID] [PMCID]

[10] Wang SJ, Zheng CJ, Peng C, Zhang H, Jiang YP, Han T, et al. Plants and cervical cancer: an overview. Expert Opin Investig Drugs. 2013; 22(9):1133-56. [DOI:10.1517/13543784.2013.81148 6] [PMID]

[11] Zaid H, Silbermann M, Amash A, Gincel D, Abdel-Sattar E, Sarikahya NB. Medicinal plants and natural active com- pounds for cancer chemoprevention/chemotherapy. Evid Evidence-Based Complementary and Alternative Medicine. 2017; 2017:7952417. [DOI:10.1155/2017/7952417] [PMID] [PMCID]

[12] Ognyanov I, Pyuskyulev B, Kompis I, Sticzay T, Spiteller G, Shamma M, et al. Alkaloids from Vinca herbacea W.K. X. The structures and stereochemistry of majdine and isomajdine. Tetrahedron. 1968; 24(13):4641-8. [DOI:10.1016/S00404020(01)98661-2]

[13] Pyuskyulev B, Ognyanov I, Panov P. [Alkaloids from Vinca herbacea W.K. XI. Norfluorocurarine (German)]. Tetrahedron Letters. 1967; 46:4559-62. [DOI:10.1016/S0040-4039(01)89555-1]

[14] Ognyanov I, Pyuskyulev B, Bozjanov B, Hesse M. [Alkaloids from Vinca herbacea W.K. Isolation and structure of hervin (German)]. Helvetica Chimica Acta. 1967; 50(3):754-8. [DOI:10.1002/hlca.19670500304] [PMID]

[15] Rusianov K, Zheliazkov D, Georgiev V. [On the Blocking Effect of Alkaloids Vinca herbacea W. K. On Myoneural Synapses (Bulgarian)]. Izv Inst Fiziol (Sofiia). 1963; 6:213-37. [PMID]

[16] Vachnadze V, Vachnadze N, Gogitidze N, Mushkiashvili $\mathrm{N}$, McHedlidze K. [Biologically active alkaloids from rhizomes with roots of Vinca herbacea waldst. Et Kit, growing in Georgia (Russian)]. Georgian Med News. 2017; (271):122-7. [PMID]

[17] Gagua N, Baghdikian B, Mabrouki F, Elias R, Vachnadze $\mathrm{V}$, Bakuridze A, et al. HPLC determination of majdine in Vinca herbacea. Natural Product Communications. 2011; 6(12):1831-4. [DOI:10.1177/1934578X1100601211] [PMID]

[18] Zhou XJ, Rahmani R. Preclinical and clinical pharmacology of vinca alkaloids. Drugs. 1992; 44 Suppl 4:1-16; discussion 66-9. [DOI:10.2165/00003495-199200444-00002] [PMID]

[19] Vachnadze V, Vachnadze N, Gogitidze N, Mushkiashvili $\mathrm{N}$, McHedlidze K. [Biologically active alkaloids from rhizomes with roots of Vinca herbacea waldst. et kit, growing in georgia]. Georgian Medical News. 2017; (271):122-7. [PMID]

[20] Carmichael J, DeGraff WG, Gazdar AF, Minna JD, Mitchell JB. Evaluation of a tetrazolium-based semiautomated colorimetric assay: assessment of chemosensitivity testing. Cancer Research. 1987; 47(4):936-42. https:/ / cancerres.aacrjournals. org/content/47/4/936.short

[21] Hayon T, Dvilansky A, Shpilberg O, Nathan I. Appraisal of the MTT-based assay as a useful tool for predicting drug chemosensitivity in leukemia. Leukemia \& Lymphoma. 2003; 44(11):1957-62. [DOI:10.1080/1042819031000116607] [PMID]

[22] Du GJ, Zhang Z, Wen XD, Yu C, Calway T, Yuan CS, et al Epigallocatechin Gallate (EGCG) is the most effective cancer chemopreventive polyphenol in green tea. Nutrients. 2012; 4(11):1679-91. [DOI:10.3390/nu4111679] [PMID] [PMCID]

[23] Pereira FV, Ferreira-Guimaraes CA, Paschoalin T, Scutti JA, Melo FM, Silva LS, et al. A natural bacterial-derived product, the metalloprotease arazyme, inhibits metastatic murine melanoma by inducing MMP-8 cross-reactive antibodies. PLoS One. 2014; 9(4):e96141. [DOI:10.1371/journal. pone.0096141] [PMID] [PMCID]

[24] Kumar S, Sharma VK, Yadav S, Dey S. Antiproliferative and apoptotic effects of black turtle bean extracts on human breast cancer cell line through extrinsic and intrin- 
sic pathway. Chemistry Central Journal. 2017; 11(1):56. [DOI:10.1186/s13065-017-0281-5] [PMID] [PMCID]

[25] Fan F, Wey JS, McCarty MF, Belcheva A, Liu W, Bauer TW, et al. Expression and function of vascular endothelial growth factor receptor-1 on human colorectal cancer cells. Oncogene. 2005; 24(16):2647-53. [DOI:10.1038/sj.onc.1208246] [PMID]

[26] Wilailak S, Lertchaipattanakul N. The epidemiologic status of gynecologic cancer in Thailand. Journal of Gynecologic Oncology. 2016; 27(6):e65. [DOI:10.3802/jgo.2016.27.e65] [PMID] [PMCID]

[27] Matulonis UA, Sood AK, Fallowfield L, Howitt BE, Sehouli J, Karlan BY. Ovarian cancer. Nature Reviews Disease Primers. 2016; 2:16061. [DOI:10.1038/nrdp.2016.61] [PMID] [PMCID]

[28] Cristea M, Han E, Salmon L, Morgan RJ. Practical considerations in ovarian cancer chemotherapy. Therapeutic Advances in Medical Oncology. 2010; 2(3):175-87. [DOI:10.1177/1758834010361333] [PMID] [PMCID]

[29] Anglesio MS, Wiegand KC, Melnyk N, Chow C, Salamanca C, Prentice LM, et al. Type-specific cell line models for typespecific ovarian cancer research. PLoS One. 2013; 8(9):e72162. [DOI:10.1371/journal.pone.0072162] [PMID] [PMCID]

[30] Rai Y, Pathak R, Kumari N, Sah DK, Pandey S, Kalra N, et al. Mitochondrial biogenesis and metabolic hyperactivation limits the application of MTT assay in the estimation of radiation induced growth inhibition. Scientific Reports. 2018; 8(1):1531. [DOI:10.1038/s41598-018-19930-w] [PMID] [PMCID]

[31] Fadok VA, Voelker DR, Campbell PA, Cohen JJ, Bratton DL, Henson PM. Exposure of phosphatidylserine on the surface of apoptotic lymphocytes triggers specific recognition and removal by macrophages. Journal of Immunology. 1992; 148(7):2207-16. [PMID]

[32] Elmore S. Apoptosis: A review of programmed cell death. Toxicologic Pathology. 2007; 35(4):495-16. [DOI:10.1080/01926230701320337] [PMID] [PMCID]

[33] Mohammad RM, Muqbil I, Lowe L, Yedjou C, Hsu HY, Lin LT, et al. Broad targeting of resistance to apoptosis in cancer. Seminars in Cancer Biology. 2015; 35(Suppl):S78-S103. [DOI:10.1016/j.semcancer.2015.03.001] [PMID] [PMCID]

[34] Ouyang L, Shi Z, Zhao S, Wang FT, Zhou TT, Liu B, et al. Programmed cell death pathways in cancer: A review of apoptosis, autophagy and programmed necrosis. Cell Proliferation. 2012; 45(6):487-98. [DOI:10.1111/j.13652184.2012.00845.x] [PMID] [PMCID]

[35] Gulcin I, Beydemir S, Topal F, Gagua N, Bakuridze A, Bayram R, et al. Apoptotic, antioxidant and antiradical effects of majdine and isomajdine from Vinca herbacea Waldst. and kit. Journal of Enzyme Inhibition and Medicinal Chemistry. 2012; 27(4):587-94. [DOI:10.3109/14756366.2011.604318] [PMID]

[36] Findley HW, Gu L, Yeager AM, Zhou M. Expression and regulation of $B c l-2, B c l-x l$, and $B a x$ correlate with p53 status and sensitivity to apoptosis in childhood acute lymphoblastic leukemia. Blood. 1997; 89(8):2986-93. [DOI:10.1182/ blood.V89.8.2986] [PMID]

[37] Tang N, Ma L, Lin XY, Zhang Y, Yang DL, Wang EH, et al. Expression of PHF20 protein contributes to good prognosis of NSCLC and is associated with Bax expression.
International Journal of Clinical and Experimental Pathology. 2015; 8(10):12198-206. [PMCID] [PMID]

[38] Fan H, Li X, Wang W, Lai Q, Tang X, Gao D, et al. Effects of NMDA-receptor antagonist on the expressions of $\mathrm{Bcl}-2$ and Bax in the subventricular zone of neonatal rats with hypoxia-ischemia brain damage. Cell Biochemistry and Biophysics. 2015; 73(2):323-30. [DOI:10.1007/s12013-0150586-8] [PMID]

[39] Lee JY, Jee SB, Park WY, Choi YJ, Kim B, Kim YH, et al. Tumor suppressor protein p53 promotes 2-methoxyestradiol-induced activation of Bak and Bax, leading to mitochondria-dependent apoptosis in human colon cancer HCT116 cells. Journal of Microbiolog and Biotechnology. 2014; 24(12):1654-63. [DOI:10.4014/jmb.1405.05062] [PMID]

[40] Zhou FF, Yan M, Guo GF, Wang F, Qiu HJ, Zheng FM, et al. Knockdown of eIF4E suppresses cell growth and migration, enhances chemosensitivity and correlates with increase in $\mathrm{Bax} / \mathrm{Bcl}-2$ ratio in triple-negative breast cancer cells. Medical Oncology. 2011; 28(4):1302-7. [DOI:10.1007/ s12032-010-9630-0] [PMID]

[41] Stark AM, Hugo HH, Tscheslog H, Mehdorn HM. p53, $B c l-2$ and $B A X$ in non-small cell lung cancer brain metastases: A comparison of real-time RT-PCR, ELISA and immunohistochemical techniques. Neurological Research. 2007; 29(5):435-40. [DOI:10.1179/016164107X165282] [PMID]

[42] Bashyam MD. Understanding cancer metastasis: An urgent need for using differential gene expression analysis. Cancer. 2002; 94(6):1821-9. [DOI:10.1002/cncr.10362] [PMID]

[43] Leake I. Colorectal cancer: Understanding the routes of metastasis in colorectal cancer. Nature Reviews Gastroenterology \& Hepatology. 2014; 11(5):270. [DOI:10.1038/ nrgastro.2014.60] [PMID]

[44] Sun SY. Understanding the role of the death receptor 5/ FADD/caspase-8 death signaling in cancer metastasis Molecular and Cellular Pharmacology. 2011; 3(1):31-4. [PMCID] [PMID]

[45] D'Arrigo G, Navarro G, Di Meo C, Matricardi P, Torchilin V. Gellan gum nanohydrogel containing anti-inflammatory and anti-cancer drugs: A multi-drug delivery system for a combination therapy in cancer treatment. European Journal of Pharmaceutics and Biopharmaceutics. 2014; 87(1):208-16. [DOI:10.1016/j.ejpb.2013.11.001] [PMID]

[46] Lu J, Zhang K, Nam S, Anderson RA, Jove R, Wen W. Novel angiogenesis inhibitory activity in cinnamon extract blocks VEGFR2 kinase and downstream signaling. Carcinogenesis. 2010; 31(3):481-8. [DOI:10.1093/carcin/ bgp292] [PMID] [PMCID]

[47] Goel HL, Mercurio AM. VEGF targets the tumour cell. Nature Reviews Cancer. 2013; 13(12):871-82. [DOI:10.1038/ nrc3627] [PMID] [PMCID]

[48] Beaufort CM, Helmijr JC, Piskorz AM, Hoogstraat M, Ruigrok-Ritstier K, Besselink N, et al. Ovarian cancer cell line panel (OCCP): Clinical importance of in vitro morphological subtypes. PLoS One. 2014; 9(9):e103988. [DOI:10.1371/ journal.pone.0103988] [PMID] [PMCID]

[49] Stetler-Stevenson WG. The role of matrix metalloproteinases in tumor invasion, metastasis, and angiogenesis. Surgi- 
cal Oncology Clinics of North America. 2001; 10(2):383-92. [DOI:10.1016/S1055-3207(18)30071-1]

[50] Garzetti GG, Ciavattini A, Lucarini G, Goteri G, de e Nictolis M, Garbisa S, et al. Tissue and serum metalloproteinase (MMP-2) expression in advanced ovarian serous cystoadenocarcinomas: Clinical and prognostic implications. Anticancer Research. 1995; 15(6B):2799-804. [PMID]

[51] Fishman DA, Bafetti LM, Banionis S, Kearns AS, Chilukuri K, Stack MS. Production of extracellular matrix-degrading proteinases by primary cultures of human epithelial ovarian carcinoma cells. Cancer. 1997; 80(8):1457-63. [DOI:10.1002/(SICI)1097-0142(19971015)80:83.0.CO;2-4]

[52] Lopata A, Agresta F, Quinn MA, Smith C, Ostor AG, Salamonsen LA. Detection of endometrial cancer by determination of matrix metalloproteinases in the uterine cavity. Gynecologic Oncology. 2003; 90(2):318-24. [DOI:10.1016/ S0090-8258(03)00328-7]

[53] Torng PL, Mao TL, Chan WY, Huang SC, Lin CT. Prognostic significance of stromal metalloproteinase- 2 in ovarian adenocarcinoma and its relation to carcinoma progression. Gynecologic Oncology. 2004; 92(2):559-67. [DOI:10.1016/j.ygyno.2003.11.011] [PMID] 
Appendix 1. List of primers used in this study

\begin{tabular}{|c|c|}
\hline Gene Symbols & Primer Sequences $\left(5^{\prime}->3^{\prime}\right)$ \\
\hline $\mathrm{Bcl}-2-\mathrm{F}$ & TGTGTGGAGAGCGTCAACC \\
\hline $\mathrm{Bcl}-2-\mathrm{R}$ & TGGATCCAGGTGTGCAGGT \\
\hline Bax-F & GATGCGTCCACCAAGAAGC \\
\hline Bax-R & AAGTCCAATGTCCAGCCCAT \\
\hline VEGFR1-F & CCAGACCCAGCTCTCTACCC \\
\hline VEGFR1-R & CGCCAGCACCACTTGATTGT \\
\hline VEGFR2-F & GCCTACCTCACCTGTTTCCT \\
\hline VEGFR2-R & ACTGTCCGTCTGGTTGTCAT \\
\hline VEGF-A-F & AGGGCAGAATCATCACGAAGT \\
\hline VEGF-A-R & AGGGTCTCGATTGGATGGCA \\
\hline MMP2-F & AGCGGTCACAGCTACTTCTT \\
\hline MMP2-R & GCCAGTCGGATTTGATGCTT \\
\hline MMP9-F & CTTTGACAGCGACAAGAAGTGG \\
\hline MMP9-R & GGCACTGAGGAATGATCTAAGC \\
\hline GAPDH-F & AGGGCTGCTTTTAACTCTGGT \\
\hline GAPDH-R & CCCCACTTGATTTTGGAGGGA \\
\hline
\end{tabular}

ImMunoRegulation 